\title{
Decreasing sperm quality: findings from a 10 year gap longitudinal analysis of 2300 sperm samples from Brazil
}

\author{
Diminuição na qualidade seminal: achados na análise longitudinal de \\ 2300 amostras no Brasil em 10 anos
}

\author{
Edson Borges Jr., MD, Ph.D..$^{a, b}$; Amanda Souza Setti, B.Sc.a, ; Livia Vingris, B.Sc. ${ }^{a}$; Rita de Cassia Savio Figueira, M.Sc. ; \\ Daniela Paes de Almeida Ferreira Braga, M.Sc. ${ }^{a, b}$; Assumpto Iaconelli Jr., MD..$^{a, b}$ \\ a Fertility - Centro de Fertilização Assistida - Accredited Redlara center: Av. Brigadeiro Luis Antonio, 4545 - São Paulo \\ - SP, Brazil. Zip: 01401-002 \\ ${ }^{\mathrm{b}}$ Instituto Sapientiae - Centro de Estudos e Pesquisa em Reprodução Humana Assistida - Rua Vieira Maciel, 62 - São \\ Paulo - SP, Brazil. Zip: 04503-040
}

\begin{abstract}
Objective: The objective of this study was to investigate if the seminal quality of men undergoing conventional semen analysis is deteriorating over the years.

Methods: Retrospective longitudinal cohort study analyzing the sperm count, motility and morphology of 2300 semen samples, males undergoing conventional seminal analysis, from years 2000 to 2002 and 2010 to 2012 , in an ART center in Brazil. Patients provided semen sample after 2-7 days of ejaculatory abstinence and analyses were performed according to the WHO recommendations. Periods were compared.

Results: A total of 764 sperm samples were analyzed in 2000-2002 and 1536 in 2010-2012. In the past significantly higher mean sperm concentration $/ \mathrm{ml}(61.7 \pm 69.4$ vs. $\left.26.7 \pm 27.3 \times 10^{6}, \mathrm{p}<0.001\right)$, total sperm concentration $\left(183.0 \pm 197.0\right.$ vs. $\left.82.8 \pm 89.5 \times 10^{6}, p<0.001\right)$ and percentage of normal morphology $(4.6 \%$ vs. $2.7 \%$, $\mathrm{p}<0.001$ ) were observed as compared to more recent years. The incidence of azoospermia was significantly lower in the past $(4.9 \%$ vs. $8.5 \%, p=0.001)$ as well was the incidence of severe oligozoospermia ( $15.7 \%$ vs. $30.3 \%, \mathrm{p}<0.001)$. In addition, 315 of 764 and 842 of 1536 men underwent ICSI in 2000-2002 and 2010-2012, respectively. There was no significant difference between the groups regarding the total fertilization rate $(82.5 \%$ vs. $81.3 \%, p=0.619$ ).

Conclusion: The significant time-related decline in semen quality of infertile patients emphasizes the need for further studies addressing life-style. Since the fertilization potential through ICSI appears to remain steady there is enough reason for concern: the health and fertility of future generations are at risk.
\end{abstract}

Key words: Fertility; semen; sperm morphology; sperm quality; sperm concentration; sperm motility.

\section{RESUMO}

Objetivo: O objetivo deste estudo foi investigar se a qualidade seminal dos homens submetidos à análise de sêmen convencional está se deteriorando..

Métodos: estudo de coorte longitudinal retrospectivo, comparando a contagem de esperma, motilidade e morfologia de 2300 amostras de sêmen, submetidas à análise convencional, anos de 2000 a 2002 e 2010 a 2012, em um centro de RA brasileiro. Amostras vieram de 2-7 dias de abstinência ejaculatória e as análises seguiram as recomendações da OMS.

Resultados: Foram 764 amostras de 2000-2002 e 1536 de 2010-2012. No passado foram significativamente maiores a média de concentração/ $\mathrm{ml}(61,7 \pm 69,4$ versus $26,7 \pm 27,3 \times 106, p<0,001)$, o total de espermatozóides (183,0 $\pm 197,0$ versus 82,8 $\pm 89,5 \times 106$, $\mathrm{p}<0,001)$ e percentagem de morfologia normal $(4,6 \%$ versus $2,7 \%, p<0,001)$, em comparação com o recente. A incidência de azoospermia foi significativamente menor no passado $(4,9 \%$ versus $8,5 \%, p=0,001)$, como a incidência de oligozoospermia grave (15,7\% versus $30,3 \%$, $p$ $<0,001)$. Além disso, 315 de 764 e 842 de 1536 homens submeteram a ICSI em 2000-2002 e 2010-2012, respectivamente, sem diferença significativa em relação a taxa de fertilização total ( $82,5 \%$ versus $81,3 \%, p=0,619)$. Conclusão: $O$ declínio relacionado ao tempo significativo na qualidade do sêmen de pacientes inférteis enfatiza a necessidade de novos estudos abordando estilo de vida. Uma vez que o potencial de fertilização através de ICSI parece permanecer estável há motivo suficiente para preocupação: a saúde e a fertilidade das futuras gerações estão em risco.

Palavras-chave: Fertilidade; sêmen; morfologia espermática; qualidade do esperma;

\section{INTRODUCTION}

During the past decades several reports have suggested that the quality of semen in men is globally declining (Smith et al., 1978; Bostofte et al., 1983; Bendvold, 1989; Bendvold et al., 1991; Skakkebaek et al., 2006). A meta-analysis of 61 studies found a significant global decline in the average sperm concentration from 113 to 66 million/ml among men with no history of infertility, between 1938 and 1991 (Carlsen et al., 1992). Five years later, a reanalysis of 56 studies confirmed a significant decline in sperm density only in the United States and Europe (Swan et al., 1997). In an extended meta-analysis of 101 studies, Swan et al. (2000) supported a decline in sperm density for the period from 1934 to 1996.

The essential message of the meta-analysis from Carlsen et al. (1992), that sperm density had declined globally by about $50 \%$ during the second half of the last century, 
attracted significant attention and has been a matter of debate. Since its publication, several laboratories have analyzed their own data retrospectively. Many published studies have suggested that there has been a secular decline in sperm quality (Irvine et al., 1996; Bonde et al., 1998; Younglai et al., 1998; Bilotta et al., 1999) whereas others found no significant decline in sperm quality over time (Benshushan et al., 1997; Berling \& Wolner-Hanssen, 1997; Andolz et al., 1999; Acacio et al., 2000).

To our knowledge, such an investigation has never been conducted in Latin American sub fertile couples attending an assisted fertilization center for conventional semen analysis. Therefore, the objective of this study was (i) to investigate if the seminal quality of men undergoing conventional semen analysis is deteriorating over the years; and (ii) to discuss the potential etiology and implications for human fecundity and assisted fertilization treatments.

\section{METHODS}

\section{Experimental design}

This retrospective longitudinal cohort study was performed in a private fertilization center. The sperm count, motility and morphology of 2300 semen samples originating from men undergoing conventional seminal analysis, from years 2000 to $2002(n=764)$ and 2010 to $2012(n=1536)$ were analyzed. The characteristics from semen samples collected from 2000-2002 were compared to those from samples collected from 2010-2012.

Further, in order to investigate the fertilization potential over the years we compared the fertilization rate amongst those couples who underwent intracytoplasmic sperm injection (ICSI) in 2000-2002 (315/764) and in 2010-2012 (842/1536).

A written informed consent was obtained, in which patients agreed to share the outcomes of their own exams for research purposes, and the study was approved by the local institutional review board.

\section{Semen collection and analysis}

All of the semen samples were collected in the laboratory after 2-7 days of ejaculatory abstinence After liquefaction for 30 minutes, semen samples were evaluated according to the threshold values established by the WHO (WHO, 1999). The volume of the ejaculate was determined by aspirating the liquefied sample into a graduated disposable pipette. Sperm counting and motility assessment were performed following the instructions of the counting chamber manufacturer (Makler counting chamber, Sefi Medical Instruments, Haifa, Israel). The counting chamber was heated at $37^{\circ} \mathrm{C}$ in a heating stage prior to use. The sample was homogenized, by moving gently the container, and a volume of 3-5 $\mu \mathrm{l}$ of semen sample was transferred to the center of the chamber. Sperm count was performed in 10 squares of the chamber. The total sperm count is the end concentration expressed as $10^{6}$ spermatozoa/ml. Sperm motility was assessed in 100 random spermatozoa by characterizing them as ( $i)$ grade $A$ (rapid progressive motility), grade B (progressive motility), grade C (non progressive motility) and grade $D$ (immotile) and the motility was expressed as percentages. Sperm morphology was evaluated on air-dried smears, fixed and stained by the quick-stain technique (Diff-Quick; Quick-Panoptic, Amposta, Spain). A total of 200 sperm cells were characterized as morphologically normal or abnormal and the final morphology was expressed as percentages.

\section{Statistical analysis}

Data are expressed as mean \pm standard deviation (SD) for continuous variables, and percentages were used for categorical variables. Mean values were compared by Student's $t$ parametric test or Mann-Whitney nonparametric test. Percentages were compared by the chisquared or Fisher exact test, only when the expected frequency was five or fewer. Data analysis was conducted using MINITAB 16 Software.

\section{RESULTS}

Mean male age was $35.7 \pm 7.8$ years. The general characteristics of sperm samples are shown in Table 1. A total of 764 sperm samples were analyzed in 2000-2002 and 1536 in 2010-2012. The comparison of semen sample characteristics between the two groups is shown in Table 2 and Figure 1 . Mean male age, days of abstinence and progressive sperm motility were similar between the 2000-2002 and 2010-2012 groups. In the past (20002002) significantly higher mean sperm concentration/ $\mathrm{ml}$, total sperm concentration and percentage of normal morphology were observed as compared to more recent years. The incidence of azoospermia was significantly lower in the past as well was the incidence of severe oligozoospermia (sperm concentration $<10 \times 10^{6} / \mathrm{ml}$ ). Additionally, 315 of 764 and 842 of 1536 men underwent ICSI in 2000-2002 and 2010-2012, respectively. There was no significant difference between the groups regarding the total fertilization rate. However, abnormal fertilization rate was significantly higher in the past (Table 3 ).

\section{DISCUSSION}

To our knowledge this is the first study to analyze the semen quality in a large group of Latin American sub fertile men and our data clearly shows that the quality of human semen is deteriorating over the years. The results of this study showed statistically significant differences in the seminal characteristics of the subjects analyzed between the time gap of 10 years, i.e., 2000-2002 and 2010-2012 most notably in the sperm concentration and normal sperm morphology, assessed according to the WHO criteria, favouring the period time from 2000-2002. Our results support previous reports that the quality of human semen seems to be globally declining (Carlsen et al., 1992; Irvine et al., 1996). It is important to highlight that during the study period, there were very little changes in the techniques and personnel involved in the analysis of semen. Technicians adhered to strict quality control and the equipments used were the same throughout the entire study period.

The causes of the decreasing quality in male reproductive function remain to be elucidated. It has been suggested that the increased frequency of male reproductive abnormalities reflect adverse effects of environmental or lifestyle factors, such as occupational and environmental exposures, medications, and sexually transmitted disease (Forti \& Serio, 1993). Indeed, it has been previously demonstrated that the reason for geographic variations in semen characteristics may be due to environmental, nutritional, socioeconomic or other unidentified causes (Fisch \& Goluboff, 1996; Auger \& Jouannet, 1997; Jorgensen et al., 2001).

A hypothesis has been forwarded that these changes in male reproductive function may be caused by the impact of an increasing environmental burden of estrogens (Sharpe \& Skakkebaek, 2008). This hypothesis postulates that intrauterine male fetuses exposed to high levels of estrogenic or anti-androgenic compounds, may have disorders in the development of all the major cell 
Table 1. General characteristics of analyzed semen samples $(n=2300)$

\begin{tabular}{lccc}
\hline Fertilization & $\begin{array}{c}\mathbf{2 0 0 0 - 2 0 0 2} \\
(\mathbf{n = 3 1 5})\end{array}$ & $\begin{array}{c}\mathbf{2 0 1 0 - 2 0 1 2} \\
(\mathbf{n = 8 4 2 )}\end{array}$ & $\boldsymbol{p}$-value \\
\hline Total fertilization rate (\%) & 82.5 & 81.3 & 0.619 \\
\hline $\begin{array}{l}\text { Abnormal fertilization } \\
\text { rate (1PN + 3PN) (\%) }\end{array}$ & 12.2 & 7.8 & $<0.001$ \\
\hline
\end{tabular}

Note: Values are percentages. PN: pronucleus.

Table 2. Comparison of semen sample characteristics between the two groups

\begin{tabular}{lllll}
\hline Variable & Mean & SD & Min & Max \\
\hline Male age (y-old) & 35.7 & 7.8 & 15.0 & 71.0 \\
\hline Days of abstinence & 4.2 & 2.8 & 0.0 & 30.0 \\
\hline $\begin{array}{l}\text { Semen sample } \\
\text { volume (ml) }\end{array}$ & 3.3 & 1.7 & 0.1 & 11.3 \\
\hline $\begin{array}{l}\text { Sperm concentration/ml } \\
\text { (million) }\end{array}$ & 38.3 & 46.7 & 0.0 & 540.0 \\
\hline $\begin{array}{l}\text { Total sperm } \\
\text { concentration (million) }\end{array}$ & 116.0 & 143.0 & 0.0 & 984.0 \\
\hline $\begin{array}{l}\text { Progressive sperm } \\
\text { motility (\%) }\end{array}$ & 36.9 & 18.9 & 0.0 & 84.0 \\
\hline \begin{tabular}{l} 
Sperm morphology \\
\hline
\end{tabular} & 3.4 & 2.9 & 0.0 & 16.0 \\
\hline
\end{tabular}

Note: values are mean $\pm S D$, unless otherwise noticed. SD: standard deviation; Min: minimum; Max: maximum.

Table 3. Comparison of fertilization between the two groups

\begin{tabular}{|c|c|c|c|}
\hline Variable & $\begin{array}{c}2000-2002 \\
(n=764)\end{array}$ & $\begin{array}{c}2010-2012 \\
(n=1536)\end{array}$ & $p$-value \\
\hline Male age (y-old) & $35.0 \pm 8.6$ & $35.3 \pm 8.1$ & 0.318 \\
\hline Days of abstinence & $4.2 \pm 3.1$ & $4.2 \pm 2.7$ & 0.777 \\
\hline $\begin{array}{l}\text { Sperm sample volume } \\
(\mathrm{ml})\end{array}$ & $3.4 \pm 1.8$ & $3.3 \pm 1.6$ & 0.473 \\
\hline $\begin{array}{l}\text { Sperm concentration/ } \\
\text { ml (million) }\end{array}$ & $\begin{array}{c}61.7 \pm \\
69.4\end{array}$ & $26.7 \pm 27.3$ & $<0.001$ \\
\hline $\begin{array}{l}\text { Total sperm concentra- } \\
\text { tion (million) }\end{array}$ & $\begin{array}{c}183.0 \pm \\
197.0\end{array}$ & $82.8 \pm 89.5$ & $<0.001$ \\
\hline $\begin{array}{l}\text { Progressive sperm } \\
\text { motility (\%) }\end{array}$ & $\begin{array}{l}36.4 \pm \\
18.3\end{array}$ & $36.5 \pm 19.2$ & 0.812 \\
\hline $\begin{array}{l}\text { Normal morphology } \\
(\%)\end{array}$ & 4.6 & 2.7 & $<0.001$ \\
\hline $\begin{array}{l}\text { Incidence of azoosper- } \\
\text { mia }(\%)\end{array}$ & $\begin{array}{c}38 / 764 \\
(4.9)\end{array}$ & $\begin{array}{l}131 / 1536 \\
(8.5)\end{array}$ & 0.001 \\
\hline $\begin{array}{l}\text { Incidence of severe } \\
\text { oligozoospermia (\%) }\end{array}$ & $\begin{array}{c}114 / 726 \\
(15.7)\end{array}$ & $\begin{array}{c}426 / 1405 \\
(30.3)\end{array}$ & $<0.001$ \\
\hline
\end{tabular}

Note: values are mean $\pm S D$, unless otherwise noticed. SD: standard deviation.

types within the testis, leading to impaired sperm quality (Sharpe \& Skakkebaek, 2008).

In addition, Carlsen et al. (1992) suggested that the decline in sperm quality may have an environmental etiology. Indeed, it has been suggested that the industrial expansion and demanding agricultural activity of the South America, together with repeated disrespect

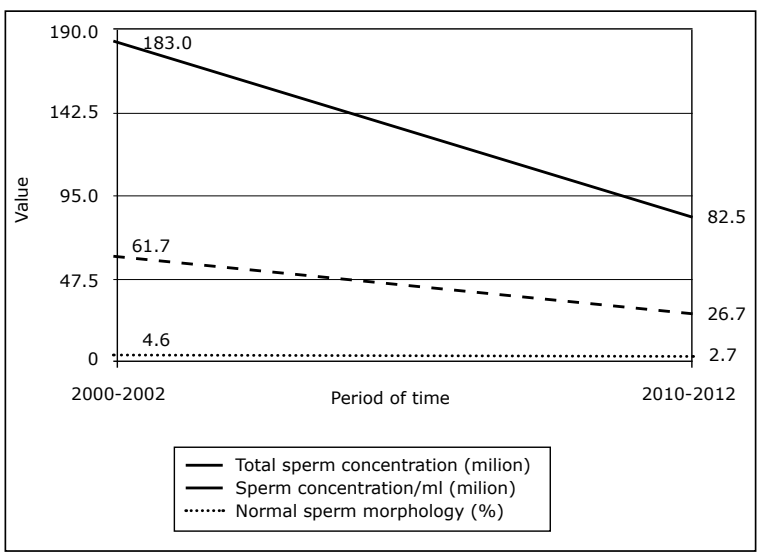

Figure 1. Illustration of differences in semen characteristics over the years

for environmental protection measures, are a risk to the health of human populations (Multigner \& Oliva, 2002). In this study we have demonstrated that sperm quality is declining over the years. However, the fertilizing potential of spermatozoa in vitro seems not to be compromised. The effects of injecting those spermatozoa are to be elucidated The rapid development in assisted reproduction therapeutic possibilities has not been accompanied by a rapid increase of knowledge on the etiology of male infertility. In ICSI, a single spermatozoon is microinjected into the oocyte after passage through the zona pellucida and the membrane of the oocyte; as a result, the spermatozoa bypass the physiological barrier for fertilization. Therefore, ICSI may be facilitating the transfer of genetic disorders to future generations.

The potential drawbacks of this study are: (i) semen samples were retrospectively included in the analysis; (ii) no data are available on the factors affecting semen quality such as occupation of the subjects, smoking, food habits and level of stress.

This study and others that suggest that sperm quality is deteriorating reinforce our awareness of the potential risks of environmental factors that can adversely affect reproductive function in men. Whether the sperm concentration has declined during the past years seems to be an endless matter of debate. As suggested by Olsen and Rachootin (2003), a monitoring system could ensure that we have a better understanding of developments over the next years.

\section{CONCLUSION}

The significant time-related decline in semen quality of infertile patients is more expressive than the reduction previously observed in fertile men. It has implications on fertility and emphasizes the need for further studies addressing subject's life-style. One of the expected consequences of these findings is an increase in the number of infertile couples. The causative agents must be found or reduced. Since the fertilization potential through ICSI appears to remain steady there is enough reason for concern: the health and fertility of future generations are at risk.

\section{Corresponding author}

Edson Borges Jr., MD, Ph.D

E-mail: edson@fertility.com.br

Address: Av. Brigadeiro Luis Antonio, 4545.

Sao Paulo - SP, Brazil. Zip: 01401-002

Phone: 5511 3018-8181 


\section{REFERENCES}

Acacio BD, Gottfried T, Israel R, Sokol RZ. Evaluation of a large cohort of men presenting for a screening semen analysis. Fertil Steril. 2000;73:595-7.

Andolz P, Bielsa MA, Vila J. Evolution of semen quality in Northeastern Spain: a study in 22,759 infertile men over a 36 year period. Hum Reprod. 1999;14:731-5.

Auger J , Jouannet P. Evidence for regional differences of semen quality among fertile French men. Federation Francaise des Centres d'Etude et de Conservation des Oeufs et du Sperme humains. Hum Reprod. 1997;12:740-5.

Bendvold E. Semen quality in Norwegian men over a 20 -year period. Int J Fertil. 1989;34:401-4.

Bendvold E, Gottlieb C, Bygdeman M, Eneroth P. Depressed semen quality in Swedish men from barren couples: a study over three decades. Arch Androl. 1991;26:189-94.

Benshushan A, Shoshani O, Paltiel O, Schenker JG , Lewin A. Is there really a decrease in sperm parameters among healthy young men? A survey of sperm donations during 15 years. J Assist Reprod Genet. 1997; 14:347-53.

Berling $S$, Wolner-Hanssen P. No evidence of deteriorating semen quality among men in infertile relationships during the last decade: a study of males from Southern Sweden. Hum Reprod. 1997;12:1002-5.

Bilotta P, Guglielmo R, Steffe M. Analysis of decline in seminal fluid in the Italian population during the past 15 years. Minerva Ginecol. 1999;51:223-31.

Bonde JP, Kold Jensen $T$, Brixen Larsen $S$, Abell A, Scheike $T$, Hjollund $\mathrm{NH}$, Kolstad HA, Ernst E, Giwercman A, Skakkebaek NE, Keiding $N$, Olsen J. Year of birth and sperm count in 10 Danish occupational studies. Scand J Work Environ Health. 1998;24:407-13.

Bostofte E, Serup J, Rebbe H. Has the fertility of Danish men declined through the years in terms of semen quality? A comparison of semen qualities between 1952 and 1972 . Int J Fertil. $1983 ; 28: 91-5$.

Carlsen E, Giwercman A, Keiding N , Skakkebaek NE. Evidence for decreasing quality of semen during past 50 years. Bmj. 1992;305:609-13.

Fisch H, Goluboff ET. Geographic variations in sperm counts: a potential cause of bias in studies of semen quality. Fertil Steril. 1996;65:1044-6.
Forti G , Serio M. Male infertility: is its rising incidence due to better methods of detection or an increasing frequency? Hum Reprod. 1993;8:1153-4.

Irvine S, Cawood E, Richardson D, MacDonald E, Aitken J. Evidence of deteriorating semen quality in the United Kingdom: birth cohort study in 577 men in Scotland over 11 years. Bmj. 1996;312:467-71.

Jorgensen N, Andersen AG, Eustache F, Irvine DS, Suominen J, Petersen JH, Andersen AN, Auger J, Cawood EH, Horte A, Jensen TK, Jouannet P, Keiding N, Vierula M, Toppari J , Skakkebaek NE. Regional differences in semen quality in Europe. Hum Reprod. 2001;16:1012-9.

Multigner L, Oliva A. Secular variations in sperm quality: fact or science fiction? Cad Saude Publica. 2002;18:403-12.

Olsen J , Rachootin P. Invited commentary: monitoring fecundity over time--if we do it, then let's do it right. Am J Epidemiol. 2003;157:94-7.

Sharpe RM, Skakkebaek NE. Testicular dysgenesis syndrome: mechanistic insights and potential new downstream effects. Fertil Steril. 2008;89:e33-8.

Skakkebaek NE, Jorgensen N, Main KM, Rajpert-De Meyts $\mathrm{E}_{\text {, }}$ Leffers H, Andersson AM, Juul A, Carlsen E, Mortensen GK, Jensen TK , Toppari J. Is human fecundity declining? Int J Androl. 2006;29:2-11.

Smith KD, Stultz DR, Jackson JR, Steinberger E. Evaluation of sperm counts and total sperm counts in 2543 men requesting vasectomy. Andrologia. 1978;10:362-8.

Swan SH, Elkin EP, Fenster L. Have sperm densities declined? A reanalysis of global trend data. Environ Health Perspect. 1997; 105:1228-32.

Swan SH, Elkin EP, Fenster L. The question of declining sperm density revisited: an analysis of 101 studies published 19341996. Environ Health Perspect. 2000;108:961-6.

WHO, eds. WHO laboratory manual for the examination of human semen and sperm-cervical mucus interaction. Cambridge, UK: Published on behalf of the World Health Organization by Cambridge University Press; 1999.

Younglai EV, Collins JA, Foster WG. Canadian semen quality: an analysis of sperm density among eleven academic fertility centers. Fertil Steril. 1998;70:76-80. 